\title{
Pengembangan Tanaman Multi Guna bagi Masyarakat di Kawasan Taman Hutan Raya Nipa-Nipa Kelurahan Gunung Jati, Kota Kendari
}

\section{(Development of Multi-Purpose Plants for Communities in the Nipa-Nipa Forest Park Area, Gunung Jati Village, Kendari City)}

\author{
Aminuddin Mane Kandari' ${ }^{1}$, La Ode Agus Salim Mando ${ }^{2 *}$, Safril Kasim ${ }^{1}$, La Ode Midi1 \\ 1 Jurusan Ilmu Lingkungan, Fakultas Kehutanan dan Ilmu Lingkungan, Universitas Halu Oleo, Jl. Mayjend S. Parman, \\ Kampus Lama Kemaraya, Kel. Lahundape, Kec. Kendari Barat, Kota Kendari 93127. \\ ${ }_{2}^{2}$ Jurusan Kehutanan, Fakultas Kehutanan dan Ilmu Lingkungan, Universitas Halu Oleo Jl. Mayjend S. Parman, \\ Kampus Lama Kemaraya, Kel. Lahundape, Kec. Kendari Barat, Kota Kendari 93127. \\ *Penulis Korespondensi: mandolaodeagussalim@gmail.com \\ Diterima September 2020/Disetujui Juli 2021
}

\begin{abstract}
ABSTRAK
Masyarakat Kelurahan Gunung Jati, Kecamatan Kendari, Kota Kendari memiliki tingkat perekonomian yang tergolong rendah di tengah desakan kebutuhan yang semakin meningkat. Hasil pertanian yang diperoleh masyarakat, dianggap masih belum mampu memenuhi kebutuhan hidup. Selain itu, mereka berada pada wilayah sekitar Taman Hutan Raya (Tahura) Nipa-Nipa yang relatif curam dan kritis, sehingga sangat dikhawatirkan bila masyarakat melakukan penebangan pohon yang dapat mengancam kelestarian hutan. Oleh karena itu, tujuan pengabdian ini adalah 1) Memberikan pemahaman kepada petani pentingnya mengembangkan tanaman multi guna dan 2) Merealisasikan konservasi hutan dengan memberikan bibit tanaman multi guna untuk ditanam di lahan andil masyarakat. Metode pelaksanaan program dilakukan berbasis masyarakat yakni melalui pelatihan budi daya tanaman multi guna disertai dengan pendampingan dengan penyuluhan serta diskusi. Hasil pengabdian ini adalah 1) Pemahaman petani mulai meningkat, yakni sekitar 18 orang (72\%) yang sudah memiliki pemahan baik-sangat baik untuk mengembangkan tanaman MPTS (Multy Purpose Tree Species) dan 2) Keberhasilan penanaman dapat dilihat dari persentase bibit yang tumbuh dan berkembang sebesar $90 \%$ yang merupakan bagian dari konservasi secara vegetatif. Kurangnya kesadaran masyarakat dalam menjaga kelestarian Tahura Nipa-Nipa termasuk dalam memelihara tanaman-tanaman yang telah diberikan, dikarenakan desakan ekonomi masih menjadi kendala serius. Oleh karena itu, tetap ada pendampingan secara berkelanjutan dengan sosialisasi dan penambahan bibit tanaman multi guna pada program selanjutnya.
\end{abstract}

Kata kunci: kelestarian hutan, kesejateraan, pengembangan tanaman multi guna, taman hutan raya Nipa-Nipa

\begin{abstract}
The people of Gunung Jati Urban Village, Kendari District, Kendari City have a relatively low economic level amidst the increasing demand. The agricultural products obtained by the community are still considered unable to meet the needs of life. In addition, they are located in the area around the Nipa-Nipa Grand Forest Park (GFP) which is relatively steep and critical, so there is great concern if the community is cutting trees that could threaten forest sustainability. Therefore, the purpose of this service are 1) To provide understanding to farmers about the importance of developing multi-purpose plants and 2) Realizing forest conservation by providing multi-purpose plant seeds to be planted on community-owned land. The method of implementing the program is community-based, namely through multi-purpose plant cultivation training accompanied by assistance with counseling and discussions. The results of this service are 1) The understanding of farmers has begun to increase, namely about 18 people $(72 \%)$ who already have a very good understanding of developing MPTS plants and 2) The success of planting can be seen from the percentage of seeds that grow and develop by $90 \%$ which is part of from vegetative conservation. Lack of public awareness in preserving the Tahura Nipa-Nipa including maintaining the plants that have been given, because economic pressure is still a serious obstacle. Therefore, there is still ongoing assistance with socialization and the addition of multi-purpose plant seeds in the next program
\end{abstract}

Keywords: forest preservation, multy purpose tree species development, Nipa-Nipa forest park, welfare 


\section{PENDAHULUAN}

Sumber daya alam merupakan karunia dan amanah dari Tuhan Yang Maha Esa yang dianugerahkan kepada Bangsa Indonesia sebagai kekayaan yang tak ternilai harganya (Jazuli 2015). Salah satu anugerah yang begitu besar tersebut adalah hutan (Mando et al. 2017). Hutan sebagai sumber daya alam yang dapat diperbaharui, perlu dikelola dengan baik. Pengelolaan hutan yang baik harus dapat memberikan manfaat yang optimal bagi masyarakat, pengelola hutan dan stakeholders serta lingkungan sekitarnya (Birgantoro \& Nurrochmat 2007). Tidak hanya itu, pengelolaan hutan yang baik juga harus memerhatikan aspek-aspek kelestarian hutan, seperti: aspek ekologi, produksi, sosial ekonomi, dan budaya masyarakat sekitar hutan (Purnawan 2006).

Kehidupan masyarakat desa sekitar hutan tidak bisa dipisahkan dari keberadaan hutan tempat mereka menggantungkan hidupnya (Birgantoro \& Nurrochmat 2007). Beberapa penelitian menunjukkan bahwa interaksi masyarakat dengan hutan cenderung tinggi ditandai dengan banyaknya masyarakat yang memenuhi kebutuhan hidup sehari-hari dari dalam kawasan hutan seperti pengambilan kayu bakar, berladang, berburu, dan kegiatan pengambilan hasil hutan non kayu (Subarna 2011; Sumanto \& Takandjandji 2014).

Konsekuensi logis dari upaya pemenuhan kebutuhan hidup masyarakat di sekitar hutan adalah tekanan terhadap hutan semakin meningkat. Tekanan terhadap hutan akan terus bertambah seiring dengan peningkatan jumlah penduduk. Menurut Zulaifah (2006), partumbuhan penduduk yang semakin tinggi di daerah pedesaan menyebabkan berbagai dampak negatif, antara lain lahan pertanian yang makin menyempit akibat bagi waris maupun akibat alih fungsi lahan, tidak tersedianya lapangan pekerjaan lain yang layak bagi angkatan kerja penduduk pedesaan, serta makin sulitnya untuk memperoleh pemenuhan kebutuhan pokok seperti sandang, pangan, dan perumahan. Hal ini juga terjadi pada masyarakat yang berada di sekitar Taman Hutan Raya (Tahura) Nipa-Nipa, Kelurahan Gunung Jati, Kota Kendari.

Kurang lebih selama sepuluh tahun terakhir ini, masyarakat Kelurahan Gunung Jati yang telah bergabung dalam Kelompok Tani Pelestari Hutan (KTPH) Sokadoliha dan Ndawi-Ndawi, telah mengusahakan berbagai tanaman di sekitar dan dalam Kawasan Tahura Nipa-Nipa. Jumlah anggota KTPH Sokadoliha sebanyak 207 orang dan Ndawi-Ndawi sebanyak 132 orang, dengan luas lahan andil yang diolah oleh masing-masing kelompok adalah 39,158 ha dan 29,621 ha (Rustam 2011). Sekitar 65\% dari anggota KTPH tidak saja bekerja sebagai petani, namun juga sebagai buruh pelabuhan.

Menjadi buruh pelabuhan dilakukan sambil menunggu hasil panen tanaman jangka pendek seperti: ketela pohon, ketela rambat, jagung, dan lain-lain. Waktu yang digunakan sebagai buruh pelabuhan mulai jam 06.00-12.00 WIB jumlah pendapatan relatif rendah kurang lebih rata-rata antara Rp 50.000-60.000/hari, belum dikurangi dengan biaya makan. Setelah itu, pada sore hari mereka fokus merawat lahan andil tersebut. Namun, bila mendekati panen para anggota tani lebih fokus pada lahan andil yang terkadang hasilnya sesuai dengan harapan dan lebih banyak tidak sesuai. Tidak sesuai lebih disebabkan oleh: 1) Hasil tanaman jangka pendek terserang hama dan penyakit; 2) Pengetahuan pengolahan lahan masih sederhana; 3) Tanah sudah kurang subur karena sering diolah; dan 4) Lahan terlalu sempit dengan rata-rata perorang sekitar 0,19 ha, dimana hasil panen pertiga bulan berkisar $\mathrm{Rp}$ 500.000-1.000.000 (Sudia et al. 2017). Penyebab ketiga dan keempat berpotensi menjadi alasan penambahan luas lahan andil oleh petani, sehingga diperlukan penambahan lahan untuk dimanfaatkan oleh masyarakat pada kawasan Tahura Nipa-Nipa. Hal ini tentunya akan menjadi masalah bila penambahan luas lahan tersebut hanya berorientasi pada tanaman pertanian jangka pendek, dimana ini tidak sesuai dengan prinsip-prinsip konservasi.

Undang-Undang Konservasi Sumber Daya Alam No 5. Tahun 1990, menyebutkan bahwa kawasan koservasi boleh dikelola asalkan tidak merubah fungsi pokok kawasan. Sejalan dengan Undang-Undang tersebut, maka berdasarkan Peraturan Daerah Provinsi Sulawesi Tenggara No. 6 Tahun 2014 tentang Pengelolaan Taman Hutan Raya (Tahura) Nipa-Nipa pada pasal 1 ayat 13 menyatakan bahwa pemanfaatan kawasan hutan adalah bentuk pemanfaatan kawasan dengan tidak mengurangi fungsi kawasan. Selanjutnya, berdasarkan pasal 1 ayat 30, kawasan hutan yang dapat dimanfaatkan berada pada blok lainya berupa blok pemanfaatan lainnya. Pemanfaatan yang dimaksud di sini sesuai dengan pasal 21 ayat 2 adalah pemanfaatan tradisional dapat berupa kegiatan pemungutan hasil hutan bukan kayu, budi daya tradisional, pengkayaan tanaman/koleksi tanaman, serta perburuan 
tradisional terbatas untuk jenis yang tidak dilindungi.

Pemanfaatan secara tradisional Tahura NipaNipa oleh masyarakat dapat dilakukan secara kolaboratif sebagaimana telah diatur dalam pasal 1 ayat 26 . Untuk menjamin kelestarian hutan dan kesejateraan masyarakat Kelurahan Gunung Jati, maka pemafaatan yang paling ideal adalah berupa pemungutan hasil hutan bukan kayu. Oleh karena itu, terbuka kesempatan bagi masyarakat untuk mengembangkan tanaman multi guna.

Pengembangan tanaman multi guna di wilayah ini praktis dibutuhkan, selain dapat memenuhi kebutuhan masyarakat berupa buah, bunga, biji, dan lain-lain di satu sisi, di sisi lain jika dijual dapat menambah pendapatan masyarakat, yang mana mayoritas pekerjaan mereka adalah sebagai buruh pelabuhan. Di samping itu, dari sisi ekologis keberadaan tanaman multi guna sangat berperan penting utamanya dalam menjaga kestabilan iklim dengan mensuplai oksigen, menyerap karbon, menjaga kesuburan lahan, dan tempat berlindungnya flora dan fauna. Adapun dari sisi hidrologis dapat mengendalikan erosi dan mengurangi debit aliran air yang akan menimpa daerah di bawahnya. Namun, saat ini masyarakat khususnya yang tergabung dalam KTPH Sokadoliha dan Ndawi-Ndawi masih kurang pengalaman dan pemahaman dalam pengembangan tanaman multi guna. Oleh karena itu, yang menjadi tujuan dari pengabdian ini adalah 1) Memberikan pemahaman kepada petani pentingnya menjaga kelestarian Taman
Hutan Raya Nipa-Nipa dengan mengembangkan tanaman multi guna dan 2) Merealisasikan konservasi hutan dengan memberikan bibit tanaman multi guna untuk ditanam di lahan andil masyarakat yang sekaligus menjadi sumber pendapatan tambahan bagi petani.

\section{METODE PELAKSANAAN}

\section{Lokasi dan Partisipan}

Pengabdian ini dilaksanakan di Kelurahan Gunung Jati, Kecamatan Kendari, Kota Kendari, tepatnya di blok pemanfaatan lainnya Kawasan Taman Hutan Raya Nipa-Nipa (Gambar 1). Kegiatan ini diselenggarakan dalam bentuk penyuluhan, pelatihan, dan penanaman langsung bibit yang telah diseleksi dengan melibatkan masyarakat (anggota kelompok tani pelestari hutan) sebanyak 33 orang dan mahasiswa yang berasal dari Fakultas Kehutanan dan Ilmu Lingkungan, Universitas Halu Oleo (FHIL UHO) sebanyak 30 orang yang dilaksanakan pada bulan Juli 2018-April 2019.

\section{Bahan dan Alat}

Bahan yang digunakan dalam pengabdian ini terdiri dari bibit pohon tanaman multi guna sebanyak 150 batang, polybag, pupuk urea, ajir, spanduk, dan kertas. Adapun alat yang digunakan seperti ember, gayung, pacul, parang, kamera digital, dan peta lokasi pengabdian. Luas lahan yang ditanami sebagai percontohan adalah 0,24 ha.

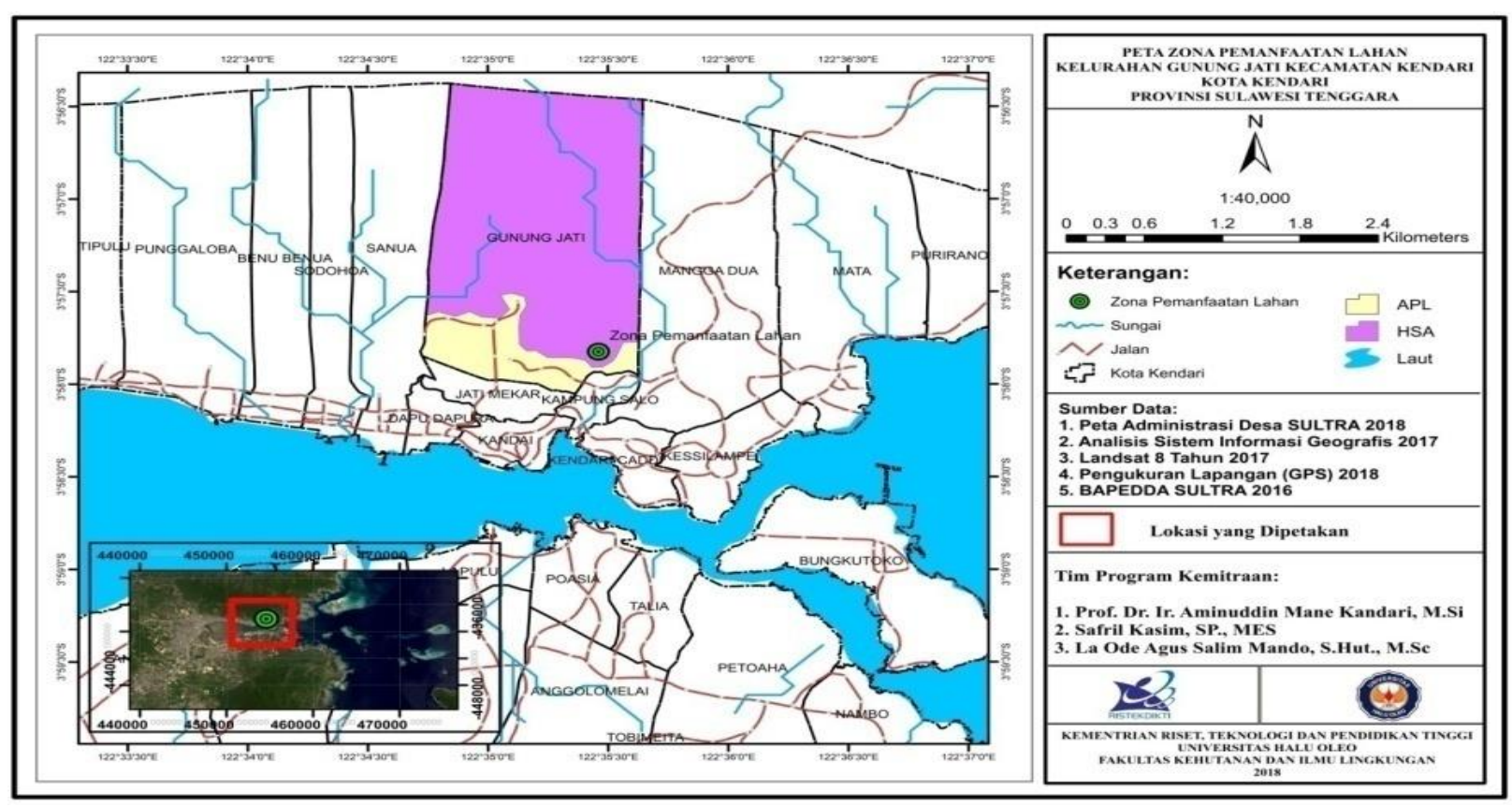

Gambar 1 Lokasi kegiatan program kemitraan masyarakat Tahun 2018. 


\section{Tahapan Pelaksanaan Kegiatan}

Pelaksanaan pengabdian bisa dikatakan berhasil manakala dilakukan melalui mekanisme pentahapan yang benar dan teratur. Mekanisme pengabdian Program Kemitraan Masyarakat (PKM) dilakukan dengan tahapan sebagai berikut:

\section{- Koordinasi dengan pihak aparat Kelurahan Gunung Jati dan Ketua Kelompok Tani Pelestari Hutan Sokadoliha dan Ndawi- Ndawi}

Koordinasi dengan pihak aparat Kelurahan Gunung Jati dalam hal ini lurah dilakukan sebagai upaya mempermudah akses dalam melakukan aktivitas di desa tersebut. Adapun dengan pihak ketua KTPH Sokadoliha sebagai mitra pertama dan Ndawi-Ndawi selaku pihak kedua dilakukan dalam rangka memudahkan konsolidasi anggota kelompok untuk berpartisipasi dalam pelaksanaan kegiatan pelatihan dan pendampingan budi daya tanaman multi guna.

\section{- Pelatihan budi daya tanaman multi guna dan seleksi bibit}

Pelatihan budi daya tanaman multi guna dilaksanakan selama satu hari pada tanggal 3 November 2018 yang dilakukan dengan memberikan penjelasan terkait dengan teknik usaha tani dan konservasi. Pemberian materi teknik usaha tani dimaksudkan agar petani mempunyai kemampuan mengorganisasi aset dan cara pertanian agar dapat meningkatkan kesejahteraan. Seperti dimulai dengan penjelasan pemilihan jenis tanaman, penanaman tanaman, pengaturan pola penanaman, dan pemeliharaan. Selanjutnya penjelasan tentang teknik seleksi bibit berkualitas dari pohon plus atau pohon yang unggul, dimana tinggi bibit dapat mencapai 70-125 cm pada umur 2-3 bulan. Masih dalam penjelasan teknik usaha tani pemilihan jenis tanaman disesuaikan dengan kebutuhan masyarakat, kesesuaian agroklimat, permintaan pasar, serta menguntungkan yang dapat diwujudkan melalui kesepakatan kelompok. Uraian tersebut juga terdapat pada brosur yang disebarkan kepada para peserta pelatihan (petani). Pada saat pelatihan tim pengabdi langsung memberikan bibit-bibit tanaman multi guna yang berkualitas sebagai contoh sebanyak 150 bibit.

Kondisi geografis Kelurahan Gunung Jati yang relatif curam, sehingga rawan longsor, banjir, dan erosi, maka pemberian materi teknik konservasi sangat penting. Penjelasan tentang teknik konservasi yang terbagi dalam empat metode, yaitu vegetatif, teknis, mekanik, dan kimiawi. Metode vegetatif adalah setiap pemanfaatan tanaman/ vegetasi maupun sisa-sisa tanaman sebagai media pelindung tanah darierosi, penghambat laju aliran permukaan, peningkatan kandungan lengas tanah, serta perbaikan sifat-sifat tanah baik sifat fisik, kimia, maupun biologi. Metode teknis adalah suatu metode konservasi dengan mengatur aliran permukaan sehingga tidak merusak lapisan olah tanah (top soil) yang bermanfaat bagi pertumbuhan tanaman, seperti: pengolahan tanah menurut kontur, pembuatan guludan, terasering, dan saluran air. Metode mekanik adalah cara pengelolaan lahan tegalan (tanah darat) dengan menggunakan sarana fisik seperti tanah dan batu sebagai sarana konservasi tanahnya, seperti: guludan, pembuatan teras gulud, teras bangku, teras individu, teras kredit, pematang kontur, teras kebun, barisan batu, dan teras batu. Metode kimiawi adalah setiap penggunaan bahan-bahan kimia baik organik maupun anorganik, yang bertujuan untuk memperbaiki sifat tanah dan menekan laju erosi seperti pemberian polyvinil alcohol (PVA), urethanised (PVAu), sodiumpolyacrylate (SPA), polyacrilamide (PAM), vinylacetate maleic acid (VAMA) copolymer, polyurethane, polybutadiene (BUT), polysiloxane, natural rubber latex, dan asphalt (bitumen).

Adapun pendampingan dilakukan selama kurang lebih 6 (enam) bulan agar dapat diketahui keberhasilan pelaksanaan program sekaligus tetap diberikan materi tambahan setiap kali kunjungan pendampingan. Kunjungan dilakukan sekali dalam sebulan dengan kegiatan berupa pemberian materi tentang teknik usaha tani dan konservasi. Selain itu, penambahan bibit tanaman dilakukan jika terdapat bibit yang mengalami kematian. Gambar 2 menunjukkan kegiatan pemberian pelatihan dan pembagian bibit MPTS (Multy Purpose Tree Species) hasil seleksi.

\section{- Penyiapan lahan dan penanaman beberapa tanaman multi guna}

Setelah bibit tersedia, maka tahap pertama adalah melakukan penyiapan lahan dan pengolahan tanah. Penyipan lahan dilakukan dengan pembersihan tanah dari tumbuhan bawah atau semak yang berukuran besar dan gulma, kemudian dikumpulkan dan dibakar. Pembakaran di dilakukan terhadap semak-semak dan gulma yang telah mati dan kering yang terjadi diawal penanaman. Selanjutnya, tanah digemburkan dengan menggunakan alat seder- 


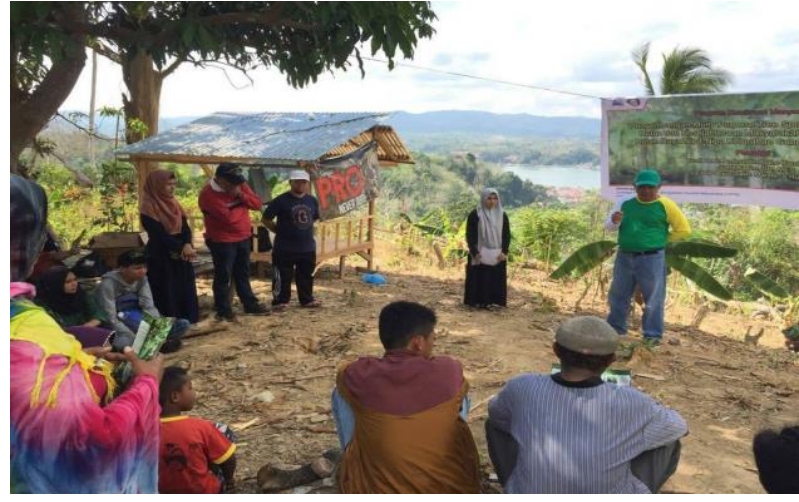

a

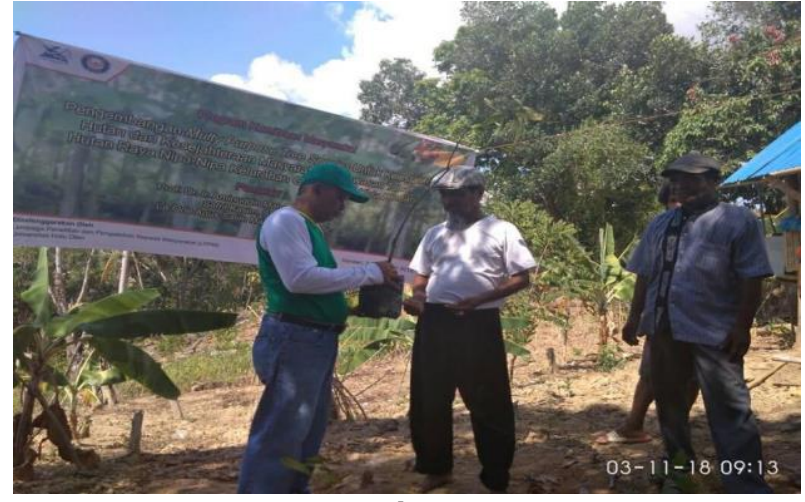

b

Gambar 2 a) Pelatihan budi daya multy purpose tree species dan 2) Pembagian Bibit multy purpose tree species hasil seleksi.

hana berupa cangkul. Tahap kedua adalah menancapkan ajir sebagai penanda tempat akan diletakkan bibit tanaman yang akan ditanam. Tahap ketiga adalah membuat lubang tanaman dengan ukuran $30 \times 30 \times 30 \mathrm{~cm}$ (Baskorowati 2014) (Gambar 3 a). Tahap keempat pemberian pupuk organik pada lubang tanaman. Tahap kelima penanaman bibit (Gambar 3 b) yang disusul penancapan kembali ajir pada bibit yang ditanam dengan ukuran jarak tanam 4 x $4 \mathrm{~m}$. Penanaman dapat dilakukan dengan cara mengkombinasikan berbagai jenis tanaman dalam satu hamparan lahan. Sebagai percontohan, bibit tanaman multi guna ditanam dengan jarak tanam $4 \mathrm{~m}$ x $4 \mathrm{~m}$ pada lahan petani dengan luas $0,24 \mathrm{ha}$.

\section{- Memantau perkembangan tanaman selama enam bulan}

Kegiatan pemantauan dilakukan sekali dalam sebulan dengan kegiatan melakukan pengamatan dan pengukuran terhadap tanaman multi guna berupa pengukuran tinggi tanaman dan diameter batang serta pengkuantifikasian jumlah daun. Selain itu, dilakukan juga pemberian penyuluhan tambahan tentang perkembangan tanaman dengan menjelaskan upaya untuk menjaga dan memperbaiki kualitas pertumbuhan tanaman, misalnya: dengan melakukan pendangiran, penyiangan, pemupukan, dan jika ada yang mati perlu dilakukan penyulaman.

\section{- Evaluasi keberhasilan kegiatan penanaman tanaman multi guna}

Setelah kegiatan PKM berakhir, maka sebagai evaluasi untuk melihat keberhasilan kegiatan yang telah dilakukan pada akhir bulan keenam. Kegiatan evaluasi bertujuan melihat perkembangan kegiatan program, masalah-masalah yang dihadapi, faktor yang menghambat, dan yang mendukung. Kemudian dari hasil kegiatan

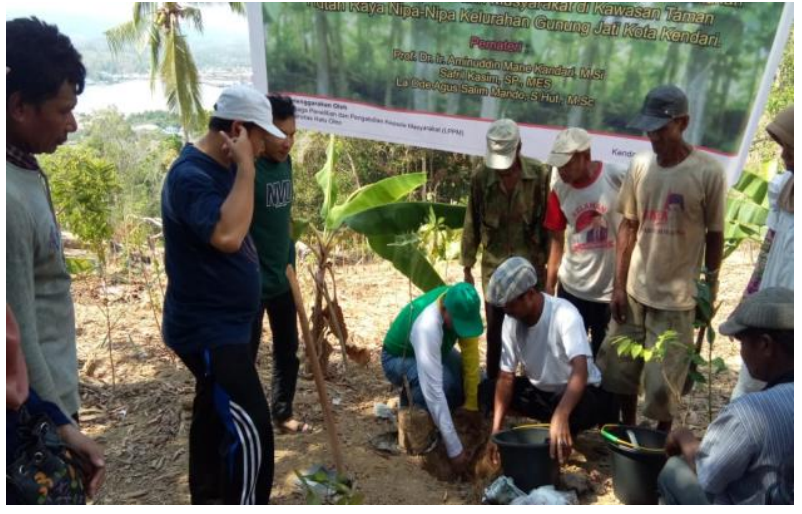

a

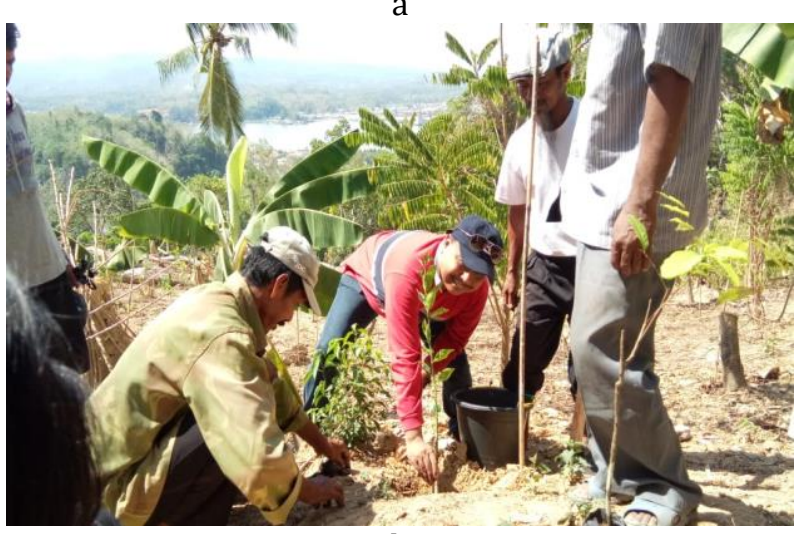

$\mathrm{b}$

Gambar 3 a) Penyiapan lubang tanam dan b) Penanaman bibit multy purpose tree species.

tersebut bisa diketahui langkah apa yang bisa ditempuh agar program yang telah terlaksana tetap berjalan dan dipertahankan. Adapun yang menjadi faktor penghambat, maka diberikan solusi yang terbaik agar tidak menjadi masalah dimasa-masa mendatang.

Termasuk juga dalam materi evaluasi adalah melihat sejauh mana efektifitas kegiatan penyuluhan yang dilakukan selama sekali dalam sebulan. Hal ini penting karena keberhasilan kegiatan program pengabdian sangat ditentukan oleh intensnya interaksi antara tim pengabdian dengan petani melalui media penyuluhan. Ke- 
berhasilan penyuluhan ditentukan oleh baiknya dalam pemberian materi sehingga mudah dicerna oleh petani dan diterapkan. Selain itu, kehadiran petani dalam kegiatan penyuluhan juga menjadi faktor yang menentukan.

Teknik evaluasi, yaitu dengan memaparkan kegiatan-kegiatan secara bersama yang telah dilakukan selama enam bulan terakhir. Kemudian membangun komunikasi dua arah dengan anggota KTPH Sokadoliha dan Ndawi-Ndawi. Sehingga, jelas dipahami apa saja yang menjadi penghambat dan masalah dalam program kemitraan masyarakat untuk selanjutnya dibuatkan solusi (Gambar 4). Adapun tahapan kegiatan secara umum dapat dilihat pada Gambar 5.

\section{Metode Pengumpulan Data}

Metode pengumpulan data dilakukan dengan tiga cara, yaitu observasi, komunikasi langsung (wawancara), dan studi bibliografis/dokumenter/pustaka. Metode observasi dilakukan dengan melakukan langsung pengamatan di lapangan terhadap bibit yang telah ditanam kegiatan pemeliharaan tanaman oleh masyarakat. Metode komunikasi langsung dilakukan dengan melakukan wawancara melalui pola

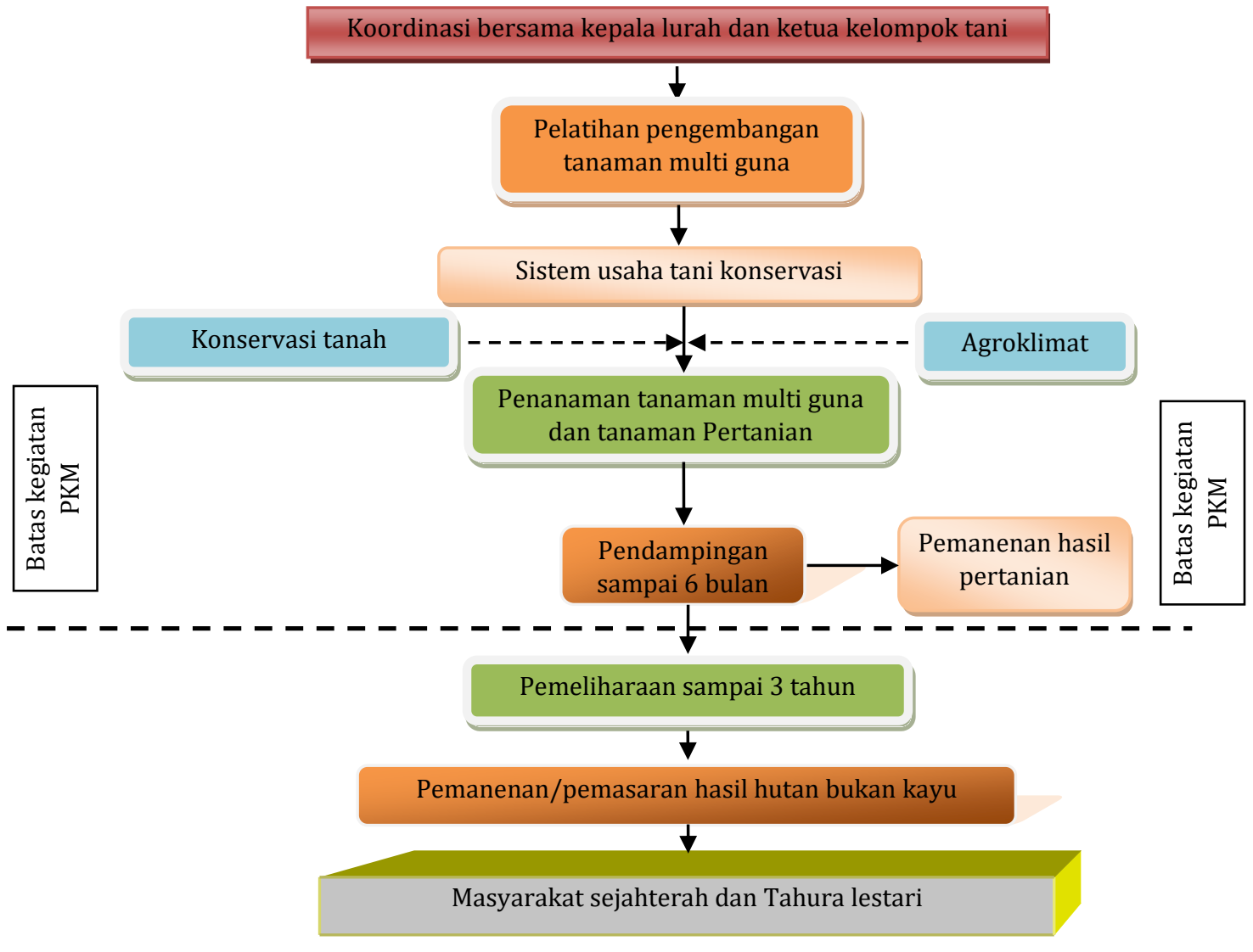

Gambar 4 Rancangan pemecahan masalah pengembangan tanaman multi guna.

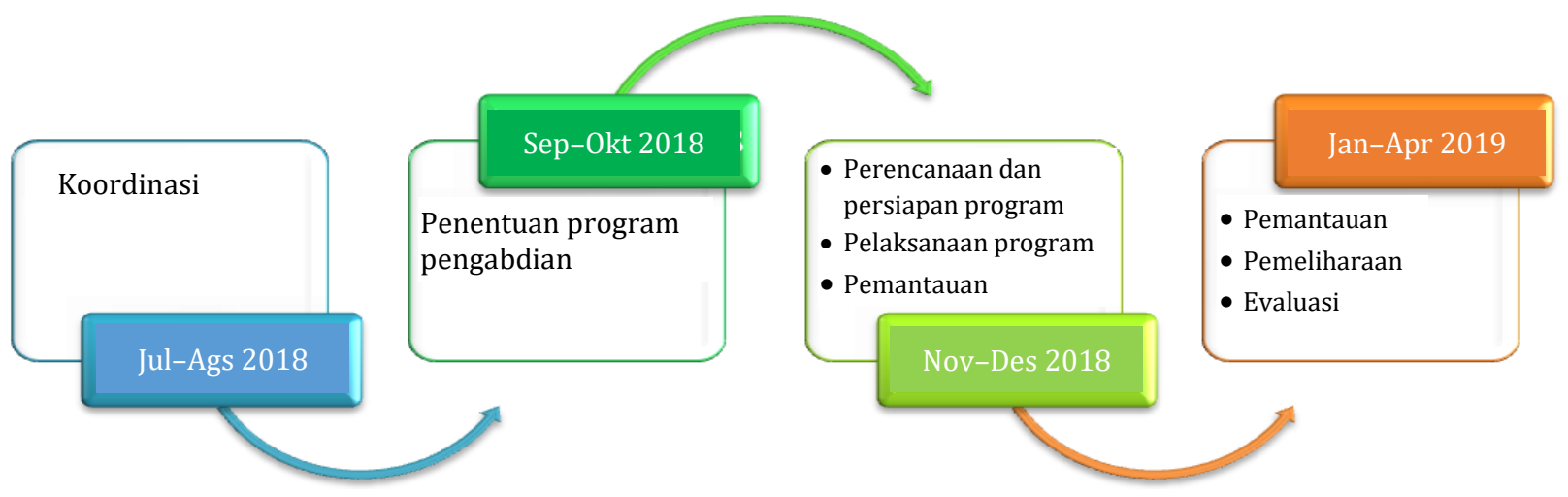

Gambar 5 Tahapan kegiatan pengabdian program kemitraan masyarakat Tahun 2018. 
diskusi secara berkelompok bersamaan dengan kegiatan penyuluhan pada setiap bulannya, sehingga yang menjadi responden adalah para petani yang hadir dalam kegiatan diskusi tersebut yang biasanya dihadiri oleh pengurus KTPH dan anggotanya. Jika ada responden kunci yang belum sempat hadir, maka wawancara akan dilakukan secara personal, sehingga jumlah responden dianggap cukup mewakili petani tersebut yang mana jumlah responden seluruhnya adalah 25 orang. Adapun metode studi pustaka adalah mengumpulkan data melalui catatan yang ada di kelurahan dan literatur yang mendukung kegiatan pengabdian.

\section{Metode Pengolahan dan Analisis Data}

Data dianalisis secara kualitatif dan kuantitatif berupa pemahaman petani terkait dengan kegiatan pengembangan tanaman MPTS dan keberhasilan upaya konservasi secara vegetatif dengan melihat jumlah bibit yang hidup dan yang mati. Pemahaman petani tentang pengembangan tanaman multi guna diukur dengan melontarkan 10 pertanyaan obyektif. Jawaban responden diberikan skor sebagai pengembangan dari skala likert, yaitu pemahaman tersebut akan terbagi menjadi sangat baik, baik, cukup baik, kurang baik, dan tidak baik. Jawaban responden, setiap nomornya nilai tertinggi adalah 1 dan nilai terendah adalah 5 , misalkan bila sangat tahu nilai 5, tahu (4), cukup tahu (3), kurang tahu (2), tidak tahu (1). Sehingga bila diakumulasikan semua jawaban tertinggi adalah 50 dan terendah adalah 10, maka akan dibuatkan interval kelas dari 5 kelas berdasarkan rumus berikut (Yasir 2014):

Interval Kelas $=\frac{\text { Nilai maksimum }- \text { Nilai minimum }}{\text { Jumlah Kelas }}$

$$
\text { Interval Kelas }=\frac{50-10}{5}
$$

Interval kelas $=8$

Maka selanjutnya dibuat tabel tingkat pemahaman petani dalam pengambangan tanaman multi guna seperti pada Tabel 1. Adapun untuk mengetahui keberhasil tindakan konservasi secara vegetatif, maka dapat hitung dari jumlah bibit yang tetap hidup sampai bulan ke-6 kegiatan. Selanjutnya, dibuatkan presentase jumlah tanaman yang tetap tumbuh, dengan rumus berikut:

$$
\text { Persentase hidup }=\frac{\text { Jumlah tanaman hidup }}{\text { Jumlah tanaman yang ditanam }} \times 100 \%
$$

Tabel 1 Tingkat pemahaman petani dalam pengembangan tanaman multi guna

\begin{tabular}{cl}
\hline Tingkat pemahaman & Kategori \\
\hline $42,00-49,99$ & Sangat Baik \\
$34,00-41,99$ & Baik \\
$26,00-33,99$ & Cukup Baik \\
$18,00-25,99$ & Kurang Baik \\
$10,00-17,99$ & Tidak Baik \\
\hline
\end{tabular}

\section{HASIL DAN PEMBAHASAN}

\section{Koordinasi dengan Pihak Aparat Kelurahan Gunung Jati dan Ketua Kelompok Tani Pelestari Hutan}

Kegiatan pelatihan dilakukan pada salah satu lahan andil anggota KTPH Sokadoliha di blok pemanfaatan lainnya. Sebelum dilakukan pelatihan, maka terlebih dahulu dilakukan koordinasi dengan pihak-pihak berkompoten di antaranya kepala lurah, Ketua KTPH Sokadoliha dan NdawiNdawi. Tokoh-tokoh kelurahan tersebut menjadi sasaran untuk ditemui karena 1) Pihak-pihak tersebut lebih memahami kondisi wilayah tersebut dan 2) Pihak-pihak tersebut yang sering berinteraksi dengan Tahura Nipa-Nipa (petani yang diwakili oleh ketua KTPH).

\section{Penentuan Program Pengabdian kepada Masyarakat}

Masyarakat di sekitar Tahura Nipa-Nipa, Kelurahan Gunung Jati dalam hal ini petani yang mengusahakan lahan andil pada umumnya merupakan kelompok masyarakat yang relatif tertinggal. Semakin bertambahnya jumlah penduduk di kelurahan tersebut, maka kebutuhan lahan dan hidup semakin meningkat, sehingga masyarakat kerapkali masuk ke dalam kawasan Tahura melakukan aktivitas perladangan yang dapat mengancam kelestarian hutan. Melalui mediasi tahun 1997, maka dibentuklah kelompok tani pelestari hutan, di Kelurahan Gunung Jati terbentuk dua KTPH, yaitu Sokadoliha dan Ndawi-Ndawi.

Jumlah anggota KTPH Sokadoliha sebanyak 207 orang dan Ndawi-Ndawi sebanyak 132 orang. Anggota KTPH yang diberikan kesempatan mengusahakan lahan di dalam kawasan hutan Tahura Nipa-Nipa adalah masyarakat dengan tingkat ekonomi rendah dengan penghasilan diperkiran sekitar Rp 500.000$1.000 .000 /$ bulan. Selain bertani, mereka juga 
mencari usaha serabutan lain seperti menjadi buruh pelabuhan dan buruh bangunan untuk dapat menyambung hidup. Ada sekitar 65\% ( \pm 220 orang) anggota selain menjadi petani juga menjadi buruh. Oleh karena itu, perlu diberikan solusi agar pendapatan petani ikut meningkat dengan menawarkan kegiatan pengabdian dalam skema program kemitraan masyarakat. Pengembangan tanaman multi guna MPTS diharapkan mampu menjadi solusi meningkatkan pendapatan petani sekaligus dapat menjaga kelestarian hutan. Program ini sudah sejalan dengan kebijakan pemerintah pusat melalui Kementerian Lingkungan Hidup dan Kehutanan (KLHK).

Peraturan Menteri Lingkungan Hidup dan Kehutanan Republik Indonesia No P.33/ MenLHK-Setjen/2015 tentang Pedoman Pembangunan Kebun Bibit Kesatuan Pengelolaan Hutan pada lampiran menyebutkan bahwa jenis tanaman serbaguna (MPTS) adalah jenis tanaman yang menghasilkan kayu dan bukan kayu antara lain berupa buah-buahan, getah, dan kulit. Sementara itu, Marpaung et al. (2015) menyebutkan bahwa tanaman MPTS merupakan tanaman yang sewaktu-waktu dapat menghasilkan uang baik dari kayu atau buah.

\section{Koordinasi dengan Pihak-Pihak yang Berkompoten Lainnya}

Peranan mahasiswa dalam pengabdian ini tak kalah penting. Bersama mahasiswa, tim kegiatan pengabdian mempersiapkan segala sesuatu yang dibutuhkan selama di lapangan sesuai dengan kebutuhan pengabdian. Mahasiswa yang dilibatkan kurang lebih 30 orang. Peranan mahasiswa di antaranya: mencari informasi keberadaan dan memperisapkan bibit serbaguna, mempersiapkan pupuk, pacul, konsumsi, dan lain-lain.

Kegiatan pengabdian mempunyai manfaat yang begitu besar bilamana diketahui juga oleh khalayak umum. Agar bisa diketahui oleh khalayak umum, maka harus diberitakan melalui media, baik media cetak maupun elektronik. Tim kegiatan pengabdian selanjutnya berkoordinasi dengan pihak media seperti Rakyat Sultra, Sultra TV, Zona Sultra. Com, Berita Kota dan lain-lain seperti terlihat pada Gambar 6.

\section{Penyuluhan, Pelatihan, dan Penanaman Pohon}

Setelah koordinasi dengan seluruh pihak berjalan lancar dan baik, maka pelaksanaan kegiatan pengabdian siap dilaksanaan. Namun, sebelumnya dilakukan perencanaan dan persiapan sebelum melaksanakan kegiatan di

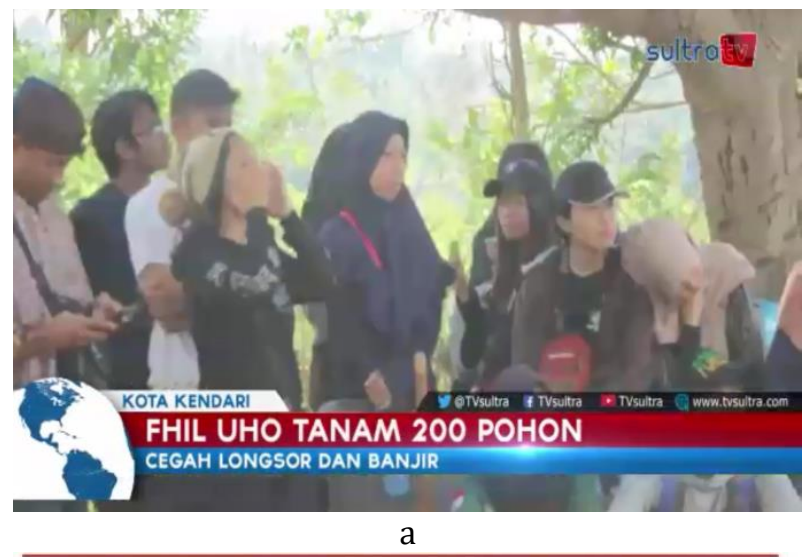

Cegah Bencana di Tahura, FHIL Tanam Tanaman Multi Fungsi

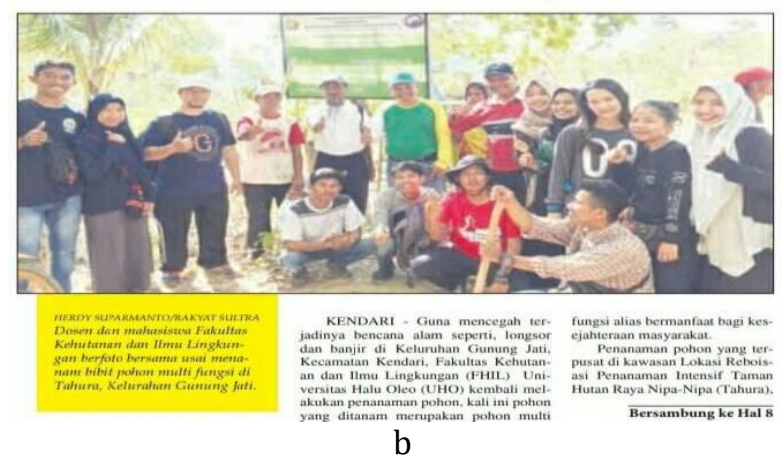

Gambar 6 a dan b Pemberitaan media kegiatan program kemitraan masyarakat Tahun 2018.

lapangan. Kegiatan penyuluhan dan pelatihan disertai dengan penanaman tanaman multi guna dilangsungkan pada tanggal 3 November 2018 bertempat di Kawasan Penanaman Intensif Tahura Nipa-Nipa, Kelurahan Gunung Jati, Kota Kendari. Kegiatan ini diikuti oleh 33 orang petani dan 30 mahasiswa FHIL UHO, yang acara pelaksanaannya berlangsung dalam tiga sesi penting, yaitu pemberian materi oleh tim peneliti, sesi diskudi dan sesi penyerahan bibit, alat dan bahan pertanian, dan penanaman pohon multi guna.

Materi pelatihan diberikan oleh tiga orang pemateri. Materi pertama berjudul fungsi tanaman multi guna sebagai stabilisator iklim global. Materi kedua berjudul metode seleksi bibit tanaman multi guna yang berkualitas unggul, dan materi ketiga berjudul metode pengembangan tanaman multi guna untuk meningkatkan kesejahteraan masyarakat. Materi diberikan secara berurutan yang mendapat antusiasme dari masyarakat.

\section{Pemantauan, Pemeliharaan, dan Evaluasi}

Pemantauan dilakukan oleh satu orang anggota tim pengabdian dibantu dengan dua orang mahasiswa yang terlaksana sampai bulan April tahun 2019. Ternyata ditemukan jumlah ta- 
naman yang hidup dan mati dari tanaman yang ditanam seperti pada Gambar 7. Jenis tanaman multi guna yang ditanam pada kegiatan program kemitraan masyarakat di kawasan Tahura NipaNipa pada blok pemanfaatan lainnya berjumlah 150 pohon, yaitu cengkeh (Syzygium aromaticum) berjumlah 30 batang, pala (Myristica fragrans) berjumlah 30 batang, durian (Durio zibethinus) berjumlah 30 batang, mangga (Mangifera) berjumlah 20 batang, jeruk (Citrus) berjumlah 20 batang, dan rambutan (Nephelium lappaceum) berjumlah 20 batang. Adapun jenis yang mempunyai persentase hidup lebih besar adalah mangga dan rambutan masing-masing sebesar 95\%. Sementara itu, yang paling banyak mengalami kematian adalah pala dan durian masing-masing sebesar 13,33\% Gambar 8.

Jumlah persentase tanaman yang hidup ratarata adalah $90 \%$, tidak menjadikan hal tersebut sebuah keniscayaan keberhasilan pada umur muda, akan tetapi itu adalah hanya bagian indikator. Sebab keberhasilan selanjuntnya adalah bila mana tanaman-tanaman yang masih tetap bertahan perlu pemeliharaan dengan baik oleh petani. Tanaman multi guna yang menga- lami kematian, selanjutnya harus dilakukan tindakan pemeliharaan berupa penyulaman. Selain itu, dilakukan pula tindakan pemeliharaan yang lain berupa pendangiran, penyiangan, dan pemupukan berupa pupuk kandang. Hal ini dilakukan agar tanaman yang telah direncanakan untuk hidup dapat terealisasi dengan baik. Sehingga, diharapkan tanaman multi guna dapat memberikan hasil panen non kayu yang dapat meningkatkan pendapatan petani, sekaligus tetap mempertahankan keseimbangan ekosistem. Hasil peneltian di beberapa wilayah di Indonesia menunjukkan keberhasilan pengembangan tanaman MPTS.

Kondisi hutan rakyat di Wonogiri serupa dengan kondisi hutan rakyat di Kabupaten Purworejo (Suryaningsih et al. 2012), petani menanam tanaman kayu, tanaman multiguna (MPTS), dan tanaman bawah tegakan. Tanaman MPTS yang ditanam, yaitu bambu, pete, durian, cengkeh, rambutan, pisang, dan melinjo. Tanaman yang ditanam di bawah tegakan adalah empon-empon, yaitu temulawak, lengkuas, kapulaga, kunyit, sereh, dan tanaman pangan (umbi-umbian) seperti singkong, talas, dan

Jumlah tanaman multi guna yang ditanam, tumbuh, dan mati

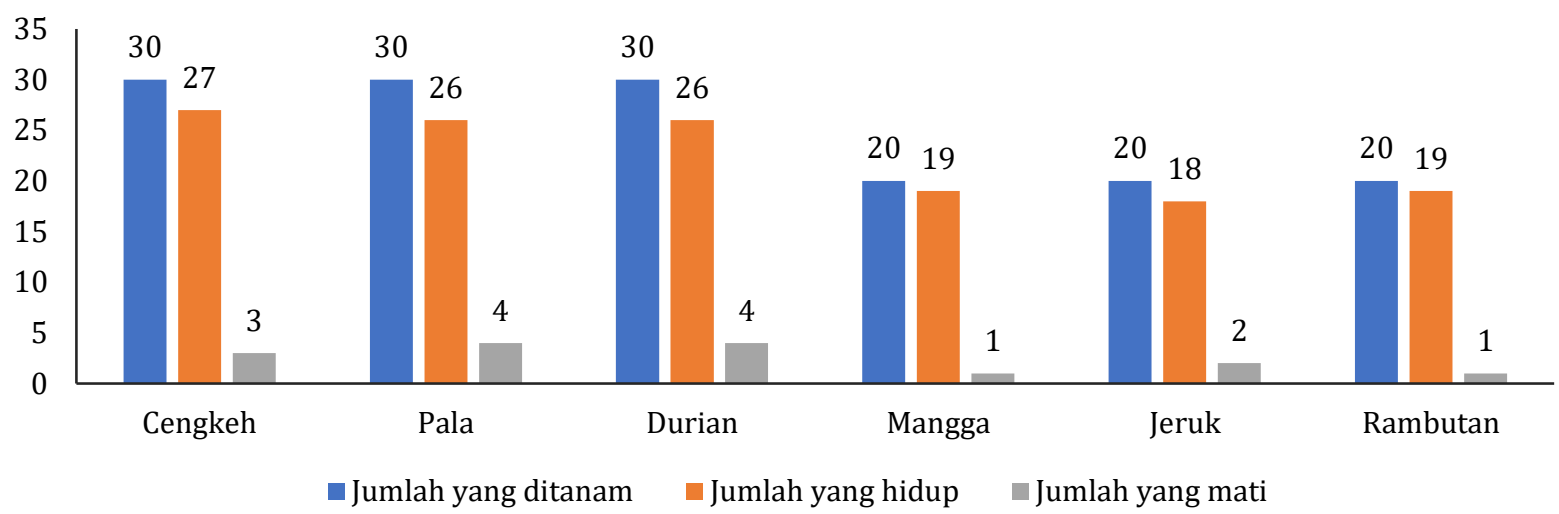

Gambar 7 Jumlah tanaman multi guna yang ditanam, tumbuh, dan mati.

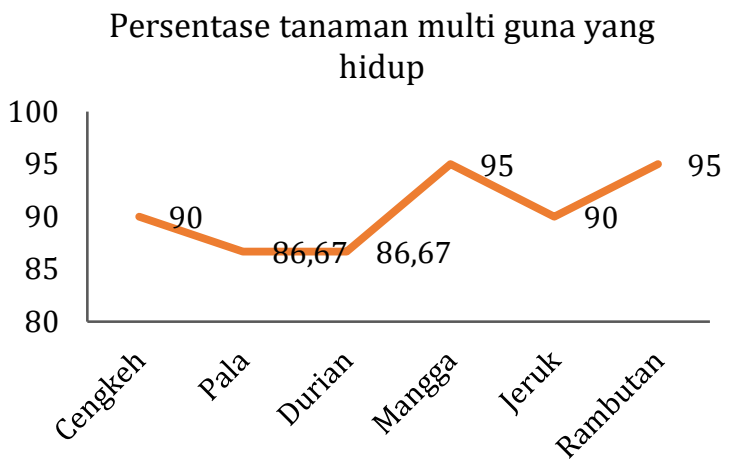

a

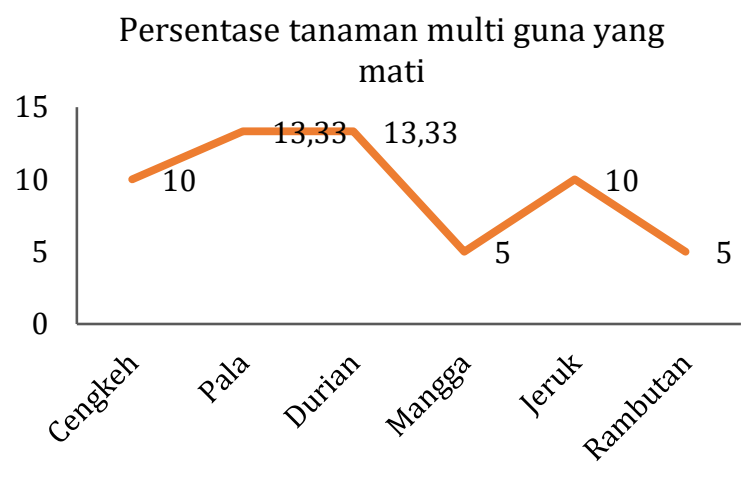

b

Gambar 8 a) Persentase tanaman multi guna yang hidup dan b) Persentase tanaman multi guna yang mati. 
suweg. Sistem agroforestri memungkinkan masyarakat dapat memenuhi kebutuhan harian, jangka menengah, dan jangka panjang (Awang et al. 2002).

Kendala yang dihadapi di lapangan adalah masyarakat masih terfokus pada pemeliharaan jenis tanaman pertanian, seperti jangung, ubi kayu, dan lain-lain, sehingga belum memerhatikan kehadiran tanaman multi guna yang dapat memberikan perbaikan ekosistem sekaligus dapat meningkatkan pendapatan masyarakat. Petani hanya menunggu bantuan bibit dari pemerintah maupun dari lembaga lainnya. Selain itu, tidak semua masyarakat memahami pentinggnya keberadaan taman hutan raya sebagai kawasan penyangga di bawahnya.

Setelah diberikan pemahaman dengan baik tentang pentingnya pengembangan MPTS melalui beberapa contoh yang ada di Indonesia, perlahan pemahaman dan kesadaran mereka pun juga meningkat. Hal ini dapat dilihat dari pengambilan data tingkat pemahaman petani Kelurahan Gunungati pada akhir kegiatan (bulan ke-6) pada Tabel 2. Berdasarkan Tabel 2 jelas bahwa terdapat tiga orang yang pemahamannya sangat baik, 15 orang baik, dan 4 orang cukup. Bila ditotalkan, maka dapat disimpulkan bahwa jumlah petani yang sudah memahi dengan baik berjumlah 18 orang atau sekitar $72 \%$ dari kategori baik sampai sangat baik.

Pengembangan tanaman multi guna memiliki prospek yang lebih besar untuk berhasil di budidayakan pada kawasan TahurA Nipa-Nipa. Selain dari aspek iklim dan tanah yang cocok di satu sisi, di sisi lain tanaman-tanaman tersebut memiliki pertumbuhan yang cepat, sehingga cepat menghasilkan yang dapat memberikan keuntungan buat masyarakat meskipun tanpa menebang pohonnya. Tanaman ini juga mudah ditemukan di jazirah Sulawesi Tenggara. Oleh karena itu, peran pemerintah mesti lebih intensif memperhatikan masyarakat yang berada di sekitar Tahura Nipa-Nipa untuk tetap menjaga hutan dengan memberikan bantuan bibit tanaman multi guna, pupuk, dan berbagai alat pertanian lainnya dengan syarat masyarakat tidak lagi menambah luas lahan andil dari apa yg telah diberikan sebelumnya.

\section{SIMPULAN}

Pemahaman petani mulai meningkat yakni sekitar 18 orang $(72 \%)$ yang sudah memiliki pemahan baik-sangat baik untuk mengembangkan tanaman MPTS. Bibit pohon yang ditanam totalnya 150 pohon yang terdiri dari 30 batang cengkeh, 30 batang pala, 30 batang durian, 20 batang mangga, 20 batang jeruk dan 20 batang rambutan. Keberhasilan penanaman dapat dilihat dari persentase bibit yang tumbuh dan berkembang sebesar $90 \%$ dari jumlah yang ditanam pada saat pengamatan bulan ke-enam. Banyaknya bibit yang terus tumbuh dengan baik memberikan gambaran bawah tanaman multi guna sangat cocok dikembangkan pada blok pemanfaatan lainnya di Tahura Nipa-Nipa yang berkonsekuensi pada masyarkat dapat ikut melestarikan hutan sekaligus dapat meningkatkan pendatapannya. Selanjutnya, dibutuhkan keseriusan pemerintah terkait untuk mendukung program pengembangan tanaman multi guna di kawasan Tahura dengan memberikan bantuan bibit dan pupuk untuk menambah kuntitas tanaman dan kualitas produknya.

\section{UCAPAN TERIMA KASIH}

Ucapan terima kasih disampaikan kepada Ketua LPPM, UHO yang telah menyetujui pelaksanaan kegiatan PKM, Dekan Fakultas Kehutanan dan Ilmu Lingkungan (FHIL) yang telah mempermudah dalam proses pengusulan program. Ucapan terima kasih juga disampaikan kepada Lurah Gunung Jati yang telah memberikan akses masuk ke wilayah kelurahan dan kepada masyarakat kelompok tani pelestari hutan yang telah berpartisipasi aktif pada saat pelaksanaan kegiatan, maupun selama enam bulan proses pengamatan dan evaluasi. Ucapan terima kasih juga disampaikan kepada mahasiswa lingkup Jurusan Kehutanan yang telah berperan aktif dalam membantu terselenggaranya pengabdian sampai pelaksanaan pemantauan dan evaluasi berakhir.

Tabel 2 Tingkat pemahaman petani dalam pengembangan tanaman multi guna di Tahura Nipa-Nipa

\begin{tabular}{clrc}
\hline Tingkat pemahaman & Kategori & Jumlah (orang) & Persentase (\%) \\
\hline $42,00-49,99$ & Sangat baik & 3 & 12 \\
$34,00-41,99$ & Baik & 15 & 60 \\
$26,00-33,99$ & Cukup baik & 4 & 16 \\
$18,00-25,99$ & Kurang baik & 3 & 12 \\
$10,00-17,99$ & Tidak baik & 0 & 0 \\
\hline
\end{tabular}




\section{DAFTAR PUSTAKA}

Awang SA, Andayani W, Hmmah B, Widayati WT, Affianto A. 2002. Hutan Rakyat: Sosial Ekonomi dan Pemasaran. Yogyakarta(ID): BPFE Yogyakarta.

Baskorowati L. 2014. Budidaya Sengon Unggul (Falcataria moluccana) untuk Pengembangan Hutan Rakyat. Kerjasama Badan Penelitian dan Pengembangan Kehutanan, Balai Besar Penelitian Bioteknologi dan Pemuliaan Tanaman Hutan, dan Direktorat Jenderal Bina Usaha Kehutanan. Bogor (ID): IPB Press.

Birgantoro BA, Nurrochmat DR. 2007. Pemanfaatan Sumber daya Hutan oleh Masyarakat di KPH Banyuwangi Utara. Jurnal Manajemen Hutan Tropika. 13(3): 172-181.

Jazuli A. 2015. Dinamika Hukum Lingkungan Hidup dan Sumber Daya Alam dalam Rangka Pembangunan Berkelanjutan. Jurnal Rechtsvinding. 4(2): 181-197. https://doi. org/10.33331/rechtsvinding.v4i2.19

Mando LOAS, Hasani UO, Midi LO, Bana S. 2017. Potensi dan Struktur Tegakan Jati di Resort Polis Hutan (RPH) Madampi Kabupaten Muna Barat. Dalam: Prosoding Seminar Nasional Kuantitatif Terapan. Kendari (ID). 8 April 2017.

Marpaung S, Afifuddin D, Budi U. 2015. Inventarisasi Tanaman Mpts (Multy Purpose Tree Species) di Daerah Tangkapan Air Danau Toba Provinsi Sumatera Utara. [Internet]. [Diakses pada: 16 Oktober 2017]. Tersedia pada: http://download.portalgaruda.org/ article.php?article $=438278 \& \mathrm{val}=4112 \&$ title $=$ INVENTARISASI\%20TANAMAN\%20MPTS\%2 0(MULTY\%20PURPOSE\%20TREE\%20SPECI ES)\%20DI\%20DAERAH\%20TANGKAPAN\%2 0AIR\%20DANAU\%20TOBA\%20PROVINSI\%2 OSUMATERA\%20UTARA.

Gubernur Sulawesi Tenggara. 2014. Peraturan Daerah Provinsi Sulawesi Tenggara Nomor 6 Tahun 2014 Tentang Pengelolaan Taman Hutan Raya Nipa-Nipa.Kendari (ID). Pemerintah Provinsi Sulawesi Tenggara.

Menteri Lingkungan Hidup dan Kehutanan. 2015. Peraturan Menteri Lingkungan Hidup dan Kehutanan Republik Indonesia Nomor: P.33/MenLHK-Setjen/2015 tentang Pedoman Pembangunan Kebun Bibit Kesatuan
Pengelolaan Hutan.Jakarta (ID). Kemen LHKHK.

Purnawan R. 2006. Pemanfaatan Sumber daya Hutan Sebagai Ekoturism Berbasis Kemasyarakatan. Surili. 2(39): 14.

Rustam. 2011. Taman Hutan Raya Nipa-Nipa sebagai Paru-Paru dan Penyangga Lingkungan Kota Teluk, Kendari dan Kabupaten Konawe, Provinsi Sulawesi Tenggara. [Internet]. [Diakses pada: 15 Oktober 2017]. Tersedia pada: http://tamanhutanrayanipanipa. blogspot.com/2011/05/tahura-nipa-nipasebagai-paru-paru.html.

Subarna T. 2011. Faktor yang Mempengaruhi Masyarakat Menggarap Lahan di Hutan Lindung: Studi Kasus di Kabupaten Garut Jawa Barat. Jurnal Penelitian Sosial dan Ekonomi. 8(4): 265-275. https://doi.org/10.20886/ jpsek.2011.8.4.265-275

Suryaningsih WH, Purnaweni H, Izzati M. 2012. Persepsi dan perilaku masyarakat dalam upaya pelestarian hutan rakyat di Desa Karangrejo Kecamatan Loano Kabupaten Purworejo. Jurnal Ekosains.4(3): 27-38.

Sudia LB, Hasani UO, Mando LOAS. 2017. Bimbingan Teknis Pemanfaatan Pekarangan dengan Multy Purpose Tree Species (Tanaman Multi Guna) untuk Kelestarian Hutan dan Kesejahteraan Masyarakat di Kelurahan Gunung Jati, Kota Kendari. Dalam: Laporan Hasil Kegiatan Pengabdian kepada Masyarakat. Pengabdian Mandiri. Kendari (ID): Universitas Halu Oleo.

Sumanto E, Takandjandji M. 2014. Identifikasi Pemanfaatan Hasil Hutan oleh Masyarakat: Upaya Konservasi Sumber Daya Genetik dan Sosial Budaya. Jurnal Bulletin Plasma Nutfah. 20(1): 27$40 . \quad$ https://doi.org/10.21082/ blpn.v20n1.2014.p27-40

Presiden Republik Indonesia. 1990. Undang-Undang Republik Indonesia Nomor 5 Tahun 1990 tentang Konservasi Sumberdaya Alam Hayati dan Ekosistemnya. Jakarta (ID). Pemerintah Negara Republik Indonesia.

Yasir M. 2014. Sikap Sosial Masyarakat Desa Hutan Terhadap Kawasan Suaka Margasatwa Tanjung Peropa Di Kecamatan Laonti Kabupaten Konawe Selatan. [Skripsi]. Kendari (ID): Universitas Halu Oleo

Zulaifah S. 2006. Pemanfaatan Sumber daya Hutan Bersama Masyarakat untuk Pengembangan Kawasan Hutan Regaloh di Kabupaten Pati Jawa Tengah. [Tesis]. Semarang (ID): Universitas Diponegoro. 